S. Zapototskyi, Doctor of Science in Geography, Professor,

I. Horyn, PhD student

Taras Shevchenko National University of Kyiv, Kyiv, Ukraine

\title{
TOURIST AND RECREATIONAL POTENTIAL OF THE LVIV REGION: GEOGRAPHICAL FEATURES OF USE AND RECREATION
}

The paper determines the foundation of formation of a touristic recreational potential of Lviv region. Main contributing factors of development of tourism industry of the region are investigated. It is established that the largest reserves of recreational resources are located in Drohobych, Zhovkva, Pustomyty, Sokal and Stryj districts. Small amounts of resources are concentrated in Brody, Zhidachiv, Kamenka-Buzka, Mykolayiv, Peremyshlyansk, Radekhiv, Sambir and Turka districts.

Tourist routes of Lviv region were estimated. In particular, the most promising ones were evaluated, including the Golden Ring of the Boykivshchyna, the Russky Path - the old way through the Carpathians, Makivka - the mountain of the immortal glory of the Ukrainian Sich Riflemen.

The correlation-regression relationship between the indicators forming the tourist flows and the main components of the tourism development of the studied region was determined.

The level and intensity of current usage of the potential of the region were estimated. SWOT-analysis of touristic and recreational potential of the region was carried out. The study of a touristic and recreational sector of Lviv region has made it possible to establish that its development depends primarily on the advantageous geographical location of the region, rich natural-resource and historical and cultural potential, and the development of touristic and recreational infrastructure.

It was established that the region has all the necessary preconditions for the long-term development of cultural-cognitive, scientificeducational, religious, medical, hunting, ecological, business, sports and excursion types of the tourism industry. Particularly important and promising is the development of rural (green) tourism in the region. The development of touristic and recreational sphere of Lviv oblast depends, first and foremost, on the rational use of natural and cultural-historical resources, the reconstruction of sanatoriums and resorts, recreational and touristic establishments, the creation of material and technical base for the development of touristic and recreational industry, promotion of investment attraction, distribution of touristic product on the domestic and world markets and strengthening of international cooperation in the field of tourism and recreation.

Keywords: tourism, recreation, tourist infrastructure, Lviv region, region, touristic and recreational potential.

\section{ВИКОРИСТАННЯ КОСМІЧНИХ ТА ІНФОРМАЦІЙНИХ ТЕХНОЛОГІЙ В ЕКСКУРСІЙНО-ТУРИСТИЧНІЙ ДІЯЛЬНОСТІ}

Висвітлено досягнення в космічній сфері, які можуть бути використані в екскурсійно-туристичній діяльності. Наведено відомості про дистанційне зондування Землі, зокрема джерела отримання супутникових знімків. Окреслено завдання, які можна виконувати, спираючись на супутникові знімки та засоби їх обробки. Дано опис найуживаніших інтернет-ресурсів і програм, використання яких дає змогу візуалізувати місцевість, отримувати об'ємні зображення, прокладати марирути подорожей, визначати географічні координати, установлювати завантаженість автоиляхів. Наведено конкретні приклади використання згаданих ресурсів і технологій.

Ключові слова: дистанційне зондування Землі, супутникові зображення, GPS, маршрут, туризм.

Постановка проблеми. Космічна ера, розпочата в середині минулого століття, міцно увійшла в різноманітні сфери людського життя. Завдяки космічним технологіям $€$ змога поліпшити підготовку подорожей, збагатити їх новими об'єктами відвідування, досягти більшого комфорту і безпеки. Разом з тим відомості про відповідні досягнення, а отже, їх використання в екскурсійно-туристичній діяльності ще не набули значного поширення.

Аналіз останніх досліджень і публікацій. Існує велика кількість наукових праць, присвячених дослідженням космосу, дистанційному зондуванню Землі (Д33), а також використанню інформаційних технологій у туризмі. В останньому разі звичайно йдеться про глобальні дистриб'ютерські системи. Наукові праці, які стосуються використання Д3З у туризмі, трапляються нечасто. Значною мірою це пов'язано з тим, що ці сфрери доволі віддалені, зокрема різною професійною підготовкою носіїв відповідних знань. Із праць, що стосуються піднятої проблеми, можна виділити кілька. Наприклад, у статті [3] показано можливості дистанційного зондування Землі для з'ясування особливостей рельєфу і термічних характеристик Українських Карпат. Значну увагу водним об'єктам як потенційним об'єктам туризму приділено у праці [4]. Використання ГІС-технологій у сфері туризму висвітлено в [4]. Різноманітні відомості щодо інформаційних технологій уміщено в колективну монографію [8]. У праці [7] сказано про те, що завдяки інформаційним технологіям користувач Інтернету може виконати віртуальну подорож найвідомішими музеями світу. Інтернет-брендінгу присвячено статтю [1]
Мета роботи полягає у висвітленні можливостей, пов'язаних із використанням Д3З та інформаційних технологій у екскурсійно-туристичній діяльності.

Виклад основного матеріалу. Дистанційне зондування Землі та засоби обробки супутникової інформації дають змогу отримувати чимало відомостей, які можна використати в екскурсійно-туристичній сфері. До таких можливостей, зокрема, належать:

- візуалізація місцевості з високою якістю;

- порівняння супутникових зображень, зроблених у різний час;

- побудова об'ємних зображень;

- панорамний огляд об'єктів;

- визначення свого місцезнаходження засобами GPS

- прокладання маршрутів з визначенням їх довжини, профілю та необхідного часу на подолання;

- установлення завантаженості автошляхів;

- візуалізація атмосферних процесів;

- оцінювання екологічного стану місцевості.

Розглянемо перелічені можливості детальніше. Перші супутникові зображення Землі було отримано в 1959 р. Поступово роздільна здатність зображень ставала кращою й нині перевищує 1 м. Хоча поширення таких знімків зазвичай виконується на комерційній основі, вони періодично надходять для відкритого користування. Зокрема, супутникові знімки 3 високою роздільною здатністю можна знайти на інтернетpecypcax Google Earth, Bing Maps, Яндекс та ін. 
Із зазначених ресурсів у першу чергу згадаємо Google Earth, що належить компанії Google. Ця програма містить велику кількість опцій, які можна використовувати в екскурсійно-туристичній діяльності. Активізація програми дає змогу істотно збільшити масштаб супутникових зображень аж до такого, що на земній поверхні можна роздивитися будь-які туристичні об'єкти. Більше того, на знімках великих європейських міст добре видно людей. За їхніми скупченнями можна навіть зрозуміти, де саме розташований вхід на Ейфелеву вежу чи якийсь інший туристичний об'єкт.

Підготовка екскурсії чи туру часто потребує знань, коли саме відбулися певні події, наприклад зведення чи зникнення якогось об'єкта. Такі відомості далеко не завжди можна знайти у друкованому чи електронному вигляді. Утім, порівнюючи супутникові зображення, отримані в різний час, можна встановити, коли саме звели якийсь стадіон чи міст. У цьому разі доцільно використати програму Google Earth, яка містить від кількох до кількох десятків супутникових зображень із їх точною часовою прив'язкою.

Проте буває так, що належного супутникового зображення в широковживаних ресурсах немає. У цьому разі можна самостійно завантажити потрібний супутниковий знімок, вибравши його з архіву Геологічної служби США [6]. Особливої уваги потребують знімки супут- ників Landsat. Спочатку їх роздільна здатність становила 60-80 м, а з 1982 р. - 30 м. Ще вищою (10 м) є роздільна здатність супутників Sentinel, які почали запускати у 2014 р. Важливо, що ці знімки перебувають у відкритому доступі $[3,6]$.

У програмі Google Earth корисною є команда Search (Пошук). Варто набрати у відповідному вікні назву шуканого об'єкта (міста, села чи навіть готелю), як одразу відбудеться наближення відповідного зображення в достатній деталізації. У разі існування кількох паралельних назв необхідно виконати уточнення, зокрема зазначити, у якій саме країні знаходиться шуканий готель.

Не менш корисною $є$ опція "Прокласти маршрут". Після набору назв місць відправлення і призначення програма будує маршрут і показує його на карті. При цьому деталізуються довжина маршруту і його окремі ділянки. Більше того, програма знаходить оптимальний шлях подолання пропонованого маршруту, навіть із використанням різних видів транспорту. Наприклад, у разі подорожі на автомобілі від Києва до Парижа програма Google Earth пропонує три варіанти маршруту завдовжки від 2359 до 2402 км. Найкоротший проходить через Люблін, Познань, Ганновер, Дортмунд. У свою чергу, найкоротший шлях залізничею, що має довжину 2463 км, проходить через Львів, Краків, Вроцлав, Франкфурт-на-Майні (рис. 1).

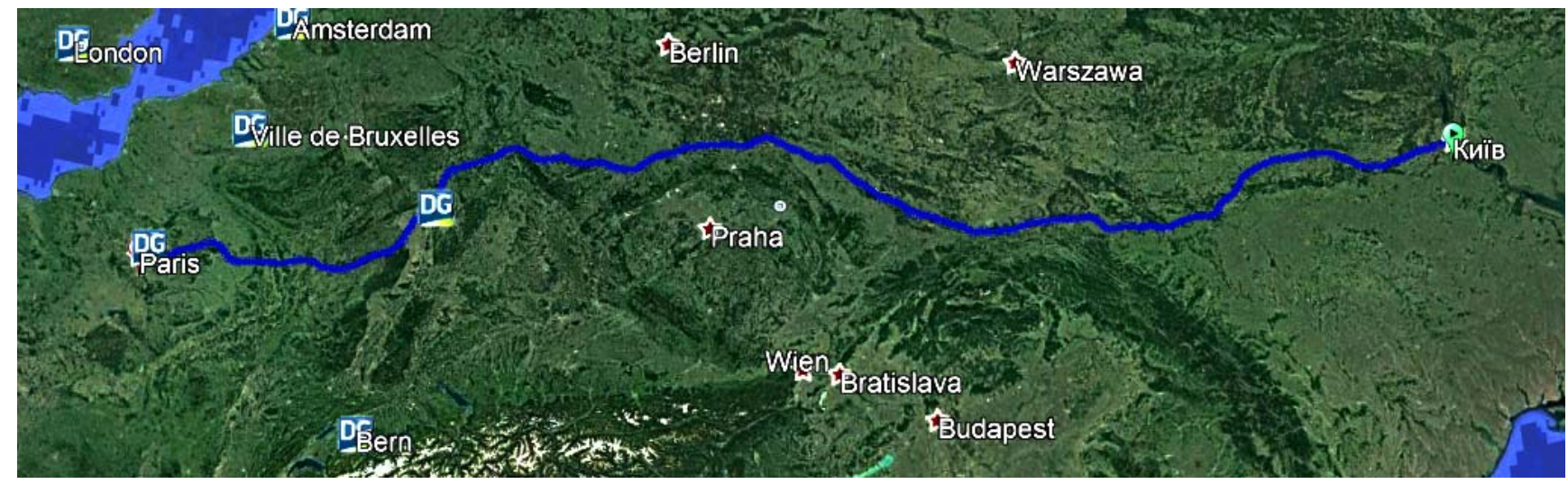

Рис. 1. Найкоротший маршрут автошляхами між Києвом і Парижем, пропонований програмою Google Earth

Корисною опцією програми Google Earth є побудова об'ємних зображень: як архітектурних об'єктів, так і елементів рельєфу. Перше здійснюється шляхом активізації фрункції 3-D, друге - фрункції "Рельєф". Відповідні дії ніби наближають користувача до місцевості, дають можливість їі оглянути з різної висоти й під різним кутом. Завдяки цьому можна здійснити омріяну (нехай і віртуальну) прогулянку центром Нью-Йорка чи Токіо. Однак зауважимо, що об'ємні зображення менш відомих міст часто є спрощеними. Наприклад, об'ємні зображення центра Києва незрівнянно гірші, ніж щойно згаданих найбільших міст США та Японії.

3 використанням програми Google Earth можна побудувати поперечний профіль марштуту, установити на ньому абсолютну висоту, а також крутизну окремих ділянок. Для цього на побудованій лінії маршруту достатньо лише натиснути правою клавішою миші. Таким способом, зокрема, можна встановити, що на автошляху від Києва до Одеси спочатку (на третині маршруту) доведеться рухатися переважно вгору, а потім униз. Великою і глибокою на цьому щляху $€$ долина р. Південний Буг. Південніше неї існує ще велика кількість значних підйомів і спусків.

Ще одним корисним додатком, який надає компанія Google, $є$ Google Maps (https://maps.google.com). Цей додаток містить таку корисну опцію як "ландшафт". Після ії̈ активізації можна вибрати місцину, що становить інтерес, і виконати віртуальну подорож. При цьому $є$ змога змінювати не лише напрямок руху, а й швидкість. Одночасно на екрані монітора чудово видно навколишні об'єкти. Додамо, що ця віртуальна подорож супроводжується показом географічних координат.

Установлення свого місцезнаходження, зокрема географічних координат, особливо актуальне під час подорожей. Цього досягають 3 використанням GPS-навігації. Вона спирається на результати функціонування 24 штучних супутників, запущених США наприкінці минулого століття. Вони перебувають на 6 кругових орбітах, розташованих під кутом $60^{\circ}$ одна до одної. Причому на кожній орбіті на однаковій відстані перебувають 4 супутники. Таке їх розташування гарантує, що над будь-якою точкою Землі одночасно $€$ щонайменше 4 супутники. Теоретично їх може бути навіть 12. Кожен супутник передає сигнали про своє розташування, а приймач, розташований на Землі, здатен не лише їх отримувати, а й перетворювати на звичні географрічні координати. Власник приймача GPS, а ними оснащено сучасні мобільні телефони, може визначити своє місцезнаходження з точністю до кількох метрів - достатньо лише активізувати опцію GPS. 
Розташування користувача відображається на дисплеї смартфону (залежно від вибору), завантаженій карті чи космічному знімку. До того жє змога визначення географічних координат, які, за потреби, можуть бути інформаційною складовою фотознімків. Планова прив'язка дає можливість установити, де саме зроблено той чи інший знімок, що реально допомагає не сплутати їх, коли таких знімків стає багато. Крім того, таким чином можна відновити маршрут.

Подібною за сутністю є Глобальна навігаційна супутникова система (ГЛОНАСС), започаткована в Радянському Союзі й завершена Росією.

Корисною, насамперед на початку подорожі, є опція "затори", активізація якої дозволяє встановити завантаженість автошляхів. Завдяки цьому можна краще оцінити необхідний час для подолання відстані, а також, за потреби, змінити маршрут. Метод, який при цьому використовується, спирається на краудсорсинг (англ. - crowdsourcing). Його сутність полягає в отриманні певної інформації (ідей, послуг) від великої кількості людей, насамперед інтернет-спільноти. Такою спільнотою на дорогах $€$ власники мобільних телефонів, швидкість пересування яких відстежується шляхом об'єднання даних мобільного зв'язку і GPS-навігації. Основна увага користувачів цієї послуги зосереджена на "пробках" (traffic jams, або traffic congestion), у яких швидкість руху є незначною.

3 компаній, які надають послуги щодо поточного стану завантаженості автошляхів, знову ж таки виділимо Google. Подібна послуга доступна й на ресурсі https://www.waze.com/livemap. У свою чергу, особливістю pecypcy http://www.tomtom.com/en_gb/trafficindex/\#/ $\epsilon$ надання користувачеві певних узагальнень, зокрема переліку міст світу, де затримки, спричинені завантаженістю доріг, найбільші.

У цьому зв'язку цікаво навести відомості про деякі "пробки", що колись траплялись. Наприклад, 23 травня 2014 р. "пробка" у м. Сан-Паулу розтяглася на 344 км. Загалом згадане місто вважається одним із найбільш перевантажених автотранспортом. Інший красномовний фракт: середня тривалість стояння у "пробках" пересічного автомобіля в м. Лос-Анжелес протягом року становить 64,4 год. (https://en.wikipedia.org/wiki/Traffic_congestion).

Задля уніфікації відповідної послуги ще в 2004 р. було розпочато, а згодом широко впроваджено Навігаційний стандарт даних (The Navigation Data Standard), яким нині дооснащуються автомобілі. Найчастіше зображення надходить на рідинно-кристалічний дисплей, вмонтований на передній панелі. Нині автомобільні навігатори продаються окремо, їхня ціна цілком доступна.

До програм, які дуже корисні В екскурсійнотуристичній сорері, можна віднести SAS.Планета. Ця програма дає змогу завантажувати велику кількість супутникових знімків і карт із використанням сервісів Google Maps, Bing Maps, Яндекс.карты, "Космоснимки". Зображення, що були хоч раз завантажені, залишаються в пам'яті комп'ютера й тому можуть бути відкриті без використання Інтернету.

Можливості:

- отримання зображень із високою роздільною здатністю;

- визначення географрічних координат об'єктів;

- прокладання маршруту і вимірювання його довжини;

- створення полігона й вимірювання його площі та периметра

- підтримка сервісу Wikimapia, що дає можливість установлення назв об'єктів;
- накладання на обране зображення одного чи кількох шарів (наприклад маршруту подорожі), їх редагування та склеювання;

- пошук об'єктів за їхньою назвою з використанням cepвicy Google;

- установлення завантаженості автошляхів;

- експорт та імпорт зображень електронною поштою.

Водночас у цій програмі відсутня опція автоматичного прокладання маршруту від початкового до кінцевого пункту призначення, яка існує в Google Maps.

Використовуючи програму SAS.Планета, дуже зручно прокладати маршрут екскурсії чи туру. Цей маршрут можна наносити на обрану основу (супутниковий знімок чи карту), а за необхідності його редагувати. Важливо, що будь-яка точка на маршруті має точні географічні координати, а довжина маршруту і його фрагментів визначається з великою точністю. Не менш важливою $€$ опція Wikimapia, яка дозволяє встановити назву об'єктів та їх призначення. Лише з використанням цієї опції можна розпочати підготовку нового екскурсійного маршруту. Подальшу його розробку виконують за допомогою вже згаданої програми Google Earth, інших інтернет-ресурсів, літературних джерел тощо.

Додамо, що програма SAS.Планета містить також історичні зображення місцевості, зокрема результати аерофотознімання Києва під час Другої світової війни. Ці знімки дають змогу відповісти на запитання про те, якою тоді була забудова міста. Те саме стосується вигляду Дніпра та його заток.

Для того, щоб у програмі SAS.Планета встановити завантаженість автошляхів, можна скористатися послідовністю команд Шари $\rightarrow$ Google $\rightarrow$ Пробки.

Складовою екскурсійно-туристичної сфери є й належна презентація підготовлених маршрутів подорожі. У цьому разі, на додаток до програми SAS.Планета, доцільно використовувати програму Adobe Photoshop. Значну привабливість має показ маршруту на карті, доповнений якісними фото, які показують об'єкти відвідування.

У самих подорожах поза відвідуваними територіями значне поширення набули GPS-навігатори, спеціально створені для туризму. Їх найголовнішими функціями $€$ не лише велика точність позиціювання, а й фріксація пройденого маршруту, показ напрямку руху до заданої точки, розрахунок швидкості пересування, необхідного часу руху тощо. Окремо має бути згадана кнопка SOS, яка в туризмі не буває зайвою. Додамо, що такі навігатори зазвичай виготовляють ударо- та водостійкими.

Близькі фрункції мають GPS-трекери - пристрої, що показують пересування відповідного приладу. Це важливо в екстремальному туризмі, оскільки дає змогу моніторити рух людини чи групи туристів навіть тоді, коли вони свідомо не повідомляють про своє місцезнаходження. Додамо, що трекери знаходять усе ширше використання в науці, за їх допомогою вивчають рух води, міграцію тварин тощо.

Важливим чинником більшості подорожей $є$ погодні умови, а використання супутникових знімків $€$ звичною практикою прогностичних центрів. До того ж існують ресурси, які надають відповідні зображення будь-якому користувачеві. Зокрема, зроблені в останні години супутникові зображення Землі містяться на сайті Українського гідрометцентру. Аналізуючи поширення хмар, можна самостійно дійти висновку, якою має бути погода найближчим часом.

У багатьох випадках туристів цікавить стан довкілля, який також можна оцінити 3 використанням космічних технологій. Навіть на звичайних супутникових знімках добре видно розташування промислових підприємств, шлейфів диму, кар'єрів з видобутку корисних копалин, 
місць скидання стічних вод. Значно більше відомостей про екологічний стан місцевості надають результати мультиспектрального знімання земної поверхні. Відповідні знімки, зокрема супутника Landsat 8, може завантажити будь-який користувач із сайту Геологічної служби США. Обробка супутникових знімків, виконана 3 використанням програми ArcGIS, дає змогу визначити стан лісового покриву, температуру води, розвиток її "цвітіння" тощо [4].

Приклад використання супутникових знімків для з'ясування чистоти води біля болгарського курорту Сонячний Берег, а відповідно вибору місця відпочинку в ньому, наведено у праці [2]. Показано, що це можна здійснити за допоміжними ознаками, зокрема за переважаючим накопиченням наносів біля наявних берегозахисних споруд. Відкладення наносів, які видно з космосу, показують, яким $є$ рух уздовжберегової течії, а відповідно й перенесення забруднень. Домінуючим тут $\epsilon$ рух води проти годинникової стрілки. Відповідно чистішою $є$ вода в північній частині курорту, куди вона надходить із відкритої частини Чорного моря.

Вартими уваги $€$ й відомості, які надають супутники Aqua i Terra, запущені США в 1999 р. Періодичність знімання певних ділянок Землі кожним із супутників - одна доба. Дуже скоро отримані зображення розміщують на сервері [9], звідки їх може завантажити будь-який користувач. Хоча роздільна здатність супутникової апаратури порівняно невисока (250 м), вона дає змогу простежувати рух хмар, оцінювати поширення снігового покриву тощо. Обираючи якусь із пропонованих опцій (Events), можна, наприклад, побачити поширення лісових пожеж.

Практичне застосування супутникових знімків високої роздільної здатності можна проілюструвати на прикладі прагнення з'ясувати наявність снігового покриву в разі планування поїздки в гори для катання на лижах.
Ідея скористуватися роботою веб-камер далеко не завжди закінчується вдало, адже вони функціонують далеко не всюди. Однак щойно зроблене супутникове зображення $є$ беззаперечним доказом існування чи відсутності снігу. Наприклад, використовуючи дані супутника Landsat 8, можна однозначно дійти висновку, що сніговий покрив в Українських Карпатах найперше з'являється на гірському хребті Чорногора. Завдяки відповідній обробці супутникових зображень можна з'ясувати, що південні схили гір істотно тепліші за північні [3].

Значне поширення гірського туризму потребує поглибленої інформації про рельєф гірських територій. Особливо цінно, коли дослідник сам здатен її отримати. Це, зокрема, можна здійснити, використовуючи дані дослідницької програми SRTM. Сутність програми, реалізованої у США у 2000 р., полягає в синхронному зніманні земної поверхні двома камерами, одна з яких змонтована на кораблі "Shuttle" (а точніше "Endeavour"), інша - на кінці прикріпленої до нього щогли. Це дало змогу одержати цифрову модель рельєфу, що нині перебуває у відкритому доступі. Потрібні супутникові знімки можна знайти за посиланням [https://earthexplorer.usgs.gov]. Boни містяться у папці Digital Elevation.

Зручним засобом обробки супутникових знімків і побудови якісних об'ємних зображень є програма Global Mapper. Програма дає змогу не лише добре візуалізувати місцевість, а й знаходити території, що мають більшу чи меншу абсолютну висоту від заданої. Використовуючи цю програму, можна отримати істотно краще уявлення про рельєф певної території, ніж навіть із найсучасніших карт. Зокрема, об'ємне зображення Українських Карпат свідчить про те, що вони $є$ майже паралельними гірськими хребтами. Спираючись на цей фракт, можна зрозуміти, що рух гребенями гір значно легший, ніж упоперек розташування гірських хребтів (рис. 2).

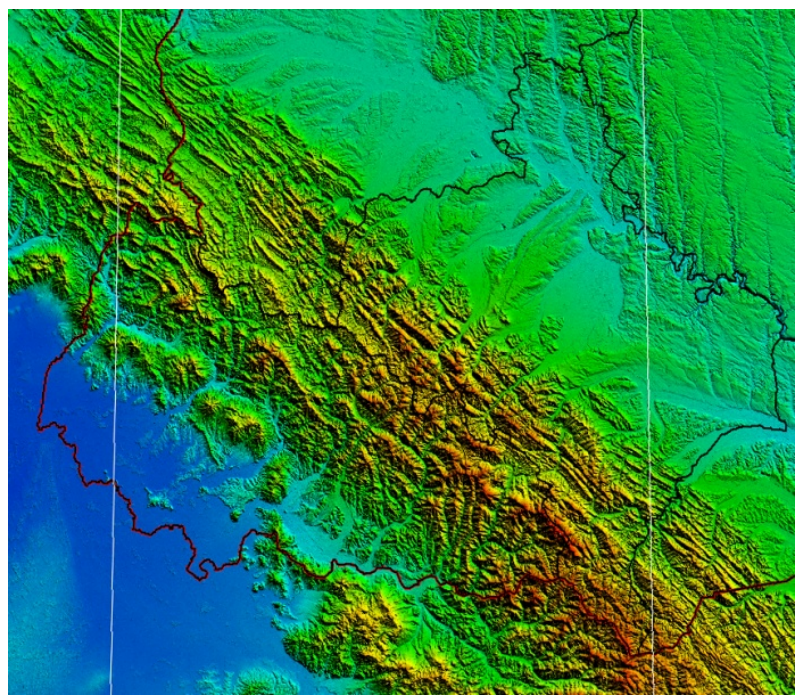

Рис. 2. Об'ємне зображення Українських Карпат, побудоване за даними SRTM

Висновки. Дані дистанційного зондування Землі та інформаційні технології можна й доцільно використовувати в екскурсійно-туристичній діяльності. Важливими перевагами супутникових знімків, порівняно з багатьма іншими джерелами інформації, є оперативність, різноманітність, висока точність, відсутність плати. Зручними для користування $€$ комп'ютерні програми Google Earth i SAS.Планета.
Список використаних джерел:

1. Авдан О. Г. Інтернет-брендінг як фрактор конкурентоспроможності туристичних підприємств / О. Г. Авдан // Економіка. Управління. Інновації. - 2013. - № 1 (9)

2. Вишневський В. І. Екологічний туризм / В. І. Вишневський. - К. : Інтерпрес LTD, 2015.

3. Вишневський В. І. Використання дистанційного зондування Землі для з'ясування термічних особливостей Українських Карпат / В. І. Вишневський, С. А. Шевчук // Укр. журн. дистанційного зондування Землі. - 2016. - № 12. - С. 47-52.

4. Вишневський В.І., Шевчук С.А. Використання даних дистанційного зондування Землі у дослідженнях водних об'єктів України /В. І. Вишневський, С. А. Шевчук. - К., 2018.

5. Геоинформационные порталы и геосервисы как инновационный элемент повышения качества услуг санаторно-курортной и турист- 
ской сферы / Н. М. Пестерова, С. М. Цыганкова, О. Ю. Боброва, И. В. Цулая // Форсайт санаторно-курортной и туристской сферы. Анапа, 2012. -С. 209-214

6. Геологічна служба США [Електронний ресурс]. - Режим доступу : www.glovis.usgs.gov.

7. Глєбова A. О. Інноваційні технології у туристичній галузі А. О. Глєбова // Економіка. Управління. Інновації. - 2012. - № 2 (8).

8. Информационное обеспечение туризма / Н. С. Морозова, М. А. Морозов, А. Д. Чудновский и др. - М. : Федеральное агентство по туризму, 2014

9. Інтерактивний браузер НАСА [Електронний ресурс]. - Режим доступу : https://worldview.earthdata.nasa.gov.

References:

1. Avdan O.G Internet-brending jak factor konkurentospromozhnosti turistuchnukh pidprijemstv. Економіка. Управління. Інновації. 2013. № 1 (9).

2. Vyshnevskyi V.I. Ecologichnyi turizm. K.: Interpres LTD. 2015. $140 \mathrm{~s}$

3. Vyshnevskyi V.I. Shevchuk S.A. Vykoristannja distansiynogo zonduvannja Zemli dlja z'jasuvannja termichnyh osoblyvostey Ukrainskyh
Karpat // Ukrainskyi zhurnal dystansiynogo zonduvannja Zemli. 2016. № 12. S. 47-52.

4. Vyshnevskyi V.I. Shevchuk S.A. Vykoristannja danyh distansiynogo zonduvannja Zemli u doslidzhennjah vodnyh ob'jektiv Ukrainy. K. 2018. 116 s.

5 . Geoinformatsionnyje portaly i geoservisy kak innovatsionny element povyshenija kachestva uslug sanatorno-kurortnoy i turistskoi sfery Pesterova N.M., Tsugankova S.M., Bobrova O.Ju., Tsulaja IV. // Forsait sanatorno-kurrortnoy i turistskoy sferu. Anapa. 2012. S. 209-214.

6. Geologichna sluzhba SSHA // elektronnyi resurs. - Rezhym dostupu: www.glovis.usgs.gov.

7. Gljebova A.O. Innovatsiyny tehnologii u turistuchniy galuzi. Economika. Upravlinna. Innovatsii. 2012. № 2 (8).

8. Informatsionnoe obespechenie turizma / Morozova N.S., Morozov M.A., Chudnovskui e dr. M.: Federalnoe agentstvo po turizmu. 2014. $288 \mathrm{~s}$.

9. Interactivny brauzer NASA // elektronnyi resurs. - Rezhym dostupu: https://worldview.earthdata.nasa.gov.

Надійшла до редколегії 15.05.18

В. Вишневский, д-р геогр. наук, проф.

Национальный авиационный университет, Киев, Украина

\section{ИСПОЛЬЗОВАНИЕ КОСМИЧЕСКИХ И ИНФОРМАЦИОННЫХ ТЕХНОЛОГИЙ В ЭКСКУРСИОННО-ТУРИСТИЧЕСКОЙ ДЕЯТЕЛЬНОСТИ}

Освещены достижения в космической сфере и информационных технологиях, которые могут быть использованы в экскурсионно-туристической деятельности. Приведены сведения о дистанционном зондировании Земли, в частности источниках получения спутниковых снимков. Определены задачи, которые можно выполнять, опираясь на спутниковые снимки и средства их обработки. Дано описание важнейших интернет-ресурсов и программ, использование которых позволяет визуализировать местность, получать объемные изображения, прокладывать маршруты путешествий, определять географические координаты, устанавливать загруженность автодорог. Приведены конкретные примеры использования упомянутых ресурсов и технологий.

Ключевые слова: дистанционное зондирование Земли, спутниковые изображения, GPS, маршрут, туризм.

V. Vyshnevskyi, Doctor of Science in Geography, Professor

National Aviation University, Kyiv, Ukraine

\section{USE OF SPACE AND INFORMATION TECHNOLOGIES IN EXCURSION AND TOURISTIC ACTIVITY}

A large number of opportunities that are connected with achievements in space and information technologies can be used in excursion and tourist activity. The most significant among those are: visualization of territory in high quality, possibility to compare satellite images taken in different time period, designing of volumetric images, panoramic review of objects, opportunity to detect someone's location via GPS determination of road traffic, visualization of processes in the atmosphere, assessment of ecological state on certain area etc. The information about remote sensing and sources of satellite images, in particular, are given. This data can be found in Google Earth program, Bing Maps, Yandex. In addition, satellite images can be found on the websites of the US Geological Service and the European Space Agency. Landsat and Sentine satellites make the most prevalent images. Quite useful options of Google Earth program are "Search" and "Create routes" as first helps to find the objects on the surface of Earth and second to create the route from one point to another. The essence of STRM mission is analyzed. This information can be applied using Global Mapper program. It gives the possibility to create volumetric images of relief which are more realistic than geographical maps. The essence of GPS is described. This system gives the opportunity to fix on the geographic coordinates which are significant in tourism. Moreover, it allows to get similar information as to photos made on routes. Another practical program, which can be employed in excursion and tourism activity, is SAS.Planet. This platform has a functional option called Wikimapia, which helps to identify object names. Furthermore, SAS.Planet allows to determine traffic congestion. This method is based on crowdsourcing. Some possible ways of ecological state assessment are described, which is also important for tourism industry. The specific examples of how to use the resources and technologies mentioned above are depicted.

Keywords: remote sensing, satellite images, GPS, route, tourism

\section{САКРАЛЬНИЙ ЛАНДШАФТ: ЗМІСТ І ФУНКЦІї}

Обґрунтовано відмінність понять "сакральний" i "релігійний". Сформульовано тлумачення сакрального ландшафтту як природної, природно-антропогенної, антропогенної системи, яка пов'язана з певними життєвими символами, міфами, вагомими подіями, релігійними почуттями й має надзвичайно ціннісне значення для людини або групи людей $i$ потребує особливого вшанування й охорони. Подано просторово-ієрархічну будову сакрального ландшафту, де можна виокремити індивідуальний, локальний регіональний, національний, глобальний рівні, розроблено класифрікацію його функцій, що мають середовищеформувальну роль. Охарактеризовано політичну, соціальну, економічну, екологічну функції сакрального ландшафту.

Ключові слова: сакральний, релісійний, сакральний ландшафт, просторова ієрархія сакрального ландшафту, класифікація функцій сакрального ландшафту.

Постановка проблеми дослідження. Сакральний світ людини, духовне, священне світосприйняття - це феномен сучасного розвитку суспільства, який є об'єктом дослідження науковців багатьох природничих, гуманітарних, соціальних наук. У географічній науці поняття сакрального ландшафту частково розглядалося в географії релігії, яка ставить за мету виявлення закономірностей формування і територіальної організації релігійних систем. Згодом географрію релігії почали називати, відповідно до терміна, запропонованого О. Шаблієм, сакральною географрією. Терміни "сакральний" і "релігійний" у географічних наукових працях уживаються як синоніми, хоча між ними є різниця. У сучасних умовах глобалізації дослідження наукових підходів щодо змісту поняття "сакра- 